\title{
Ethical considerations in adult and community education research in Nigeria: issues and perspectives
}

\author{
Sunday Olawale Olaniran ${ }^{1 *}$ (D) and Ikeoluwapo B. Baruwa ${ }^{2}$
}

\author{
* Correspondence: sundayo@uj.ac.za \\ ${ }^{1}$ Education Leadership and \\ Management, University of \\ Johannesburg, Johannesburg, South \\ Africa \\ Full list of author information is \\ available at the end of the article
}

\begin{abstract}
There is a growing international interest in ethical issues in research and the process by which it can be enhanced. Unlike in the past when research studies were conducted abruptly, almost all organisations and research institutes now have various mechanisms to ensure compliance with ethical standards and procedures. Adult and community education research in Nigeria continues to gain the attention of governments and Non-governmental organisations (NGOs) due to the need to improve the literacy rate among adult learners and out-of-school youths in the country. However, in many workshops and training involving academics and development workers, much of the discussions on ethical issues in data collection and research reportage are not given the necessary attention that it requires. This review paper explores the ethical issues in adult and community education research with a view to re-awakening the consciousness of adult education scholars and practitioners, both in Nigeria and on the continent of Africa, to rethink how research data and processes are managed, such that it conforms with best practices globally.

Keywords: Ethics, Adult education, Community education, Research, Policies and issues, Nigeria
\end{abstract}

\section{Introduction}

Research ethics is a concept that has attracted increasing attention globally, due to its complexities and dynamism. While different conceptualisations have been made about the concept, research ethics is typically presented as the protection techniques designed by researchers to ensure that all research population or participants, regardless of literacy status or cognitive competence, can participate fully without experiencing harm or persecution (DePoy and Gitlin 2019: Grady 2018). While every researcher has the freedom to conduct any study and investigate any phenomenon as deemed necessary or convenient, but by no means at the expense of the rights of the participating individual or group (Babbie and Mouton 2001). Almost all disciplines have various mechanisms to ensure that research studies comply with ethical standards and procedures. Of importance to this paper are the

(c) The Author(s). 2020 Open Access This article is licensed under a Creative Commons Attribution 4.0 International License, which permits use, sharing, adaptation, distribution and reproduction in any medium or format, as long as you give appropriate credit to the original author(s) and the source, provide a link to the Creative Commons licence, and indicate if changes were made. The images or other third party material in this article are included in the article's Creative Commons licence, unless indicated otherwise in a credit line to the material. If material is not included in the article's Creative Commons licence and your intended use is not permitted by statutory regulation or exceeds the permitted use, you will need to obtain permission directly from the copyright holder. To view a copy of this licence, visit http://creativecommons.org/licenses/by/4.0/. The Creative Commons Public Domain Dedication waiver (http://creativecommons.org/publicdomain/zero/1.0/) applies to the data made available in this article, unless otherwise stated in a credit line to the data. 
various research studies conducted in adult literacy education and community development in Nigeria and other developing countries, which mostly delve into issues regarding the socio-economic lives and wellbeing of adult members of the community. Adult literacy education occupies a significant place in the development agenda of the Nigerian government (Olaniran 2013). According to the Section 4, sub-section 67 of the country's National Policy on Education (Federal Republic of Nigeria 2013), the main objective of adult education is to:

provide functional basic education for adults and youths who have never had the advantage of formal education or who left school too early. The target groups include migrant folks, almajiri pupils, illiterate and semi-literate adults, youths and adolescents; persons who left the formal school system early and are now willing to come back and continue schooling; and other categories of disadvantaged groups; who are unable to have access to the conventional educational system and therefore require other forms of educational programmes to cater for their particular/peculiar needs and circumstances (p. 20).

To achieve this objective, the Federal Government obligated the National Commission for Mass Literacy, Adult and Nonformal Education, an agency of the government established in 1991, to coordinate the promotion of adult education programmes and research in the 36 States of the Federation, with the support of the state governments and universities in the country (Ayodele and Adedokun 2012; Zuofa 2017). Despite different programmes of the agency in promoting adult education research and practice in the country, the missing link remain the issues of ethics in data collection and management which is a crucial part of research, especially the ones involving human subjects (White 2020).

Adult education is a special form of education that requires cautious and meticulous planning due to the sensitive nature of the recipients, being adult learners. Malcolm Knowles, an American adult education scholar, captured this clearly in his postulation of an adult learning theory 'Andragogy', which he referred to as an 'art and science of helping adults learn' (Rodrigues 2012). Through this theory, Knowles reiterated the need for adult education planners and providers to design adult learning programmes with the recipients' sense of autonomy in mind (Knowles et al. 2005). In other words, adult learners come to the learning programmes from different backgrounds, and their needs and motivation must be taken into consideration during the learning programme design and implementation (Gregson and Sturko 2007; Olaniran 2020). Therefore, if adult learning requires such painstaking planning due to the nature of the learners, adult learning research requires more painstaking ethical consideration. The researchers note that in many workshops and training involving academics in Nigeria, much of the discussions around the ethical issues in data collection and research reportage are not given the adequate attention that it requires. Since many adult education scholars and research students are engaged in studies that involve adult learners in rural and urban communities, basic knowledge and application of ethics is important. In response, this paper seeks to address some ethical process and procedures that should be put into consideration when conducting research in adult and community education. 


\section{Ethics and research}

Research ethics can be traced back to the eighteenth century's early period of biomedical research, with emphasis on protecting the dignity of human participants in research activity (Akaranga and Makau 2016). This dates back to the month of December 1946 when an American filed numerous cases against twenty-three (23) German physicians and administrators (Akaranga and Makau 2016). The Germans were charged based on medical experiments conducted on some prison inmates, who were reported to have been confined in the closed concentration camps during World War II, and without their consent (Bekier 2010). While the experiments led to the deaths of many subjects, others survived lightly, although being permanently crippled. The trial precipitated the introduction of the Nuremberg Code (of 1948), which places emphasis on the liberty of withdrawal from research, the need to observe voluntary consent and the risk of security from mental, physical suffering and death (Burns and Grove 2005).

Human beings are faced with many limitations and hindrances, specifically in making some ethical decisions; and while sometimes, it is due to morality, other times it is about ethics. Ethics is generally known to be one of the most important branches of philosophy, also known as moral philosophy. Etymologically, ethics emanated from the Greek term 'ethos' which translates to custom and character (Xin 2017). This is synonymous with values and virtues that make up our everyday actions and experiences. Human beings have a wholesome capacity to think and make choices, and with that, they become solely answerable for all actions and decisions taken and made. The concept of ethics is based on the premise of good and evil, right and wrong, acceptable and unacceptable, justice and injustice, virtue and vice, basically guiding all human conduct (DeTienne et al. 2019). From a philosophical perspective, it would be germane to distinguish between the concepts of morality and ethics.

Morality and ethics are frequently used interchangeably, and therefore it is imperative to analyse the terms for better clarity. While morality emanated from the Latin term 'mores', which translates to custom and manner, ethics on the other hand emanated from the Greek term 'ethos' meaning custom and character (Baruwa 2020). From their etymology, unarguably, an examination of the concepts, highlights a rendition that the concepts could be intertwined by a layman, who has no profundity in their usage. For emphasis, considering a fair distinction between both concepts in philosophy, both can still be regarded as Siamese twins due to their interconnectedness. While morality emphasises the praxis of moral conduct (first-order set of beliefs and practices), ethics on the other hand betokens or stresses the theories guiding the former - second-order conscious reflection on the adequacy of the beliefs (Baruwa 2020).

Ethics has become so crucial in all academic endeavours, including adult and community education in that it lays importance on research and publication, and requires researchers to guard against the dignity of their subject matter. From a philosophical angle, the concept of research ethics is anchored on two philosophical perspectives, teleology and deontology. The former argues that the ends justify the means, that is, the result of the research is the major concern, and not the research process. Hence, the benefits of the research findings become paramount, with no due regard to whether the act or the process is ethical or otherwise (Frankena 2001). The latter, deontology, negates the assertion that the ends should justify the means of an unethical research, but rather advocates that the means is of utmost concern, therefore, one must act 
ethically in striving to reach the ends. For Frankena (2001), actions and rules are guided by considerations that make them right or wrong, not the positive or negative results of their consequences, therefore, an action can be wrong even if it caters for the greatest benefits of the majority, or right, if it is does otherwise. Hence, it would be wrong for a researcher to employ deceptive measures in ensuring reliability and validity of data.

Considering the aforementioned basis, it becomes expedient for a good researcher to employ appropriate literature methodology, interrogate resources or materials at disposal, and find relevant ways of collecting information and interpreting information obtained logically, amongst others. Having examined those, researchers must be open minded in their claims, with due respect to protect the need for intellectual property. Other ethical issues that should be of concern to researchers engaged in a theoretical activity include: avoidance of falsification or manipulation of materials, privacy, plagiarism, financial support, anonymity, writing and publishing ethics, confidentiality, advocacy and safety, deception, non-maleficence, informed consent, beneficence, vulnerable groups, and the like (Akaranga and Makau 2016). Hence, there is a need when conducting any form of research in education, adult education, and community education to fully consider the ethical parameters that are in relation to the subject matter.

\section{Adult and community education}

Adult education and community development can be described as two relatively new areas of study and practice when compared to fields like Philosophy, Classics, History, and the like. The subject of community development in recent times has been described as that of a relatively new term in the social sciences, as a result of its introduction in 1948. Although Anyanwu (2002) argued that the practice had long been in existence prior to the coming of the missionaries and colonial masters. Be it as it may, community development is a field that nurtures a sub field, community education, which emphasis solely lies on community ownership, partnership and direction, a responsiveness to local community-felt needs, a commitment to the principles of adult learning and a strong record in equity, accessibility and provision of services.

ACE (Aotearoa, New Zealand) cited by Findsen (2006), conceptualised community education as that organised learning activities that groups of people and individuals undertake for development (be it personal, cultural, community, or economic). It is in this view that Freire (1973) introduced a consciousness-raising process for the purpose of solving human problems, basically for motivating individuals to take action for improvement. Hence, community development education programmes can be planned, developed, designed, and most importantly aimed to meet various needs of the society such as leadership, basic economic and health issues, self-help, teamwork, stewardship and accountability, and social change.

Adult education, on the other hand, emerged in the 1960s, on the basis of economic modernisation, integration policies and social mobilisation, serving as a strategic roadmap for community and political participation of the epoch. The field of adult education in theory and practice has been described as inexhaustible due to the widening scope and focus which at times keeps revealing itself. For instance, the field of adult education has been categorised into formal, non-formal and informal. Considering the main, the focus of adult education embodies traditional adult education, nomadic education, functional literacy, female education, remedial education, liberal education, 
fundamental education, civic education, prison education, basic literacy, social and cultural education and recreational education, community education, worker education, lifelong learning, mass education, vocational education, leadership education and labour education, open distance education, prevention education, life skills education and extra mural education (Adekola 2012; Aderinonye 2004; Akintayo and Oghenekhowo 2004).

Apparently, having examined the relationship between adult education and community education, without doubt, adult and community education stresses the promotion of growth and development of the people and resources in the community. Hence, adult and community education remain pivotal in orchestrating the desired changes deemed fit for the welfare and improvement of the people or adults in the community. It is therefore important to bear in mind that while both adult education and community development are separated, but similar fields in some instances, they are both fused as one in other instances.

With due consideration to the scope and importance of adult and community education in Nigeria, it would be paramount to examine how research studies are being conducted; the ethical standards and procedures in place for adult learners; and the various mechanisms for ensuring compliance, among others.

\section{Ethical issues in adult and community education}

Over the years, there has been less concentration on ethics, specifically in the field of adult education, possibly due to the wide scope of the field and its tendency to focus on adult learners, rather than the practice. For Gordon (1997), ethics can simply not be separated from the practice of adult education. In the same vein, Brockett (1990) proposed a model for adult educators to think through when confronted with decision making on ethical issues. The essence of this model is to rightly ensure that those concerned, adult educators, are taking ethical steps and in turn, making correct decisions, rather than being wholly dependent on set guidelines. From the model's threedimensional personal value system ensures adult educators are answerable for what is of value to them. Second to that is the consideration of multiple responsibilities that asks the question of purpose, as the human subjects are responsible for a number of parties such as the learners, employers, employing organisations, professional colleagues, and society. The last dimension, operationalisation of values, asks how an individual puts their values into practice. In addition, Brockett (1990), cited by Susan (1991) posits six basic principles that can guide adult educators in their practice:

$>$ Respecting the learners with whom adult educators work,

$>$ Ensuring equity in the service rendered to the learners,

$>$ Considering the rights and responsibilities of all parties involved,

$>$ Examining if outcomes are positive and harmful, and correctly maximising the

former and minimising the latter,

$>$ Caring for the learners at their disposal,

$>$ Reflecting one's practice, that is, adult education.

Having examined the praxis, it is imperative to know that ethical issues are crucial in research, not only to general educational research, but also to issues related to the field 
of adult and community education. Adult and community educators are involved in research studies in the same manner that other fields engage in research; consequently, there are measures or principles that the researcher involved must put into consideration. Also, to avoid any harm, the institutions need to ensure that these ethical considerations are met, to guide against any harm for the institution, participants involved, researcher(s), society and other things examined in the course of the research. Therefore, it calls a fortiori to examine various ethical issues or considerations guiding research from the planning stage to the publication or submission stage.

Sieber (1996), cited by Kanukisya (2018), once suggested that, for any research to be ethical, there is a need for such to put into consideration the following principles and questions:

\footnotetext{
$>$ Seeing from the perspective of the research participants,

$>$ Searching an answer on the communication between the researcher and the participants,

$>$ Addressing the respect of privacy that is important to the participants,

$\triangleright$ Validating every possible research at the least possible risk, and lastly,

$>$ Keeping in mind the researcher's scientific perspective in relation to other scientists.
}

Further, and in corroboration with the above, for research to be tenable and accepted in adult and community education, there is a need to examine from the planning phase, the research strategies, accessibility to institutions, skills to be employed, putting in mind avoidance of harm, as this could develop not merely as a consequence for the people being studied (financial, reputational, etc.), but also for the researcher and other conjoined parties in the course of the research. Similar to avoidance of harm, is respecting the autonomy of the people involved in the research process. Adult and community education research must be done or carried out in ways that accommodates respondents and accords participants the ability to make decisions for themselves as to whether or not to participate. By this, deception will be ruled out, as it is sometimes rejected on the cause that it causes harm.

Anonymity, confidentiality, and privacy cannot be ruled out in adult and community education research, as they are of utmost concern in every research. Hence, human subjects or researchers must not divulge the respondents' sensitive information and ethnic or cultural background. (Mugenda 2003) cited by (Akaranga and Makau 2016). Though some respondents might want to be otherwise, it is thus the stance of the researcher to be proactive in ensuring privacy, confidentiality and anonymity are maintained. For instance, Ryen (2004) noted that:

There is an established and well-accepted procedure that interviewees' names and titles are given in the appendix... to deviate from this procedure may be perceived as either confusing or arrogant. This dilemma partly stems from experiences with donor projects like Western projects in local villages whose aim it is to alleviate poverty by offering grants or loans. To be selected for funding demands that your name is put on the list (Ryen 2004:233). 
To guide against this, consent forms must be clearly spelt out, thereby, adult and community education researchers must ensure that confidence and protection of information are ensured by them, and if the case may be, consent should be sought from the respondents. This, if maintained, will enhance honesty towards the research subject by protecting them from physical and psychological harm (Akaranga and Makau 2016). In addition, adult and community education researchers must be open minded in their being and belonging and must be willing to share information and ideas with community members without any form of fear and intimidation, yet still noting the intellectual property as concerned. Similarly, the researcher must be willing to treat all respondents equally, on the basis that no-one is given preferential treatment over another.

Another ethical consideration is the fabrication and falsification of data which seems common among lazy researchers. Fabrication is the act of manipulating data or results gathered, and falsification (or fraud) on the other hand has been described as the faking of equipment, materials and processes - this could be the manipulation of results obtained or the omission of some data findings (Kour and Verma 2014; Mugenda 2003) cited by (Akaranga and Makau 2016). Research should be a curiosity driven and selfmotivational activity. Therefore, anyone who engages in adult and community education research should strictly be worthy enough to refrain from acts that negate such principles and precepts.

Plagiarism, which is acknowledged by most researchers can be considered as another guiding principle in the course of writing, documenting and analysing in research. Adult and community education researchers need to ensure that every piece of writing is original and correctly supported with literature. For Akaranga and Makau (2016), introduction and literature review are areas where plagiarism are commonly noted in research. It becomes pivotal to consider, quote and cite materials used in the course of research appropriately - obviously, research comes with rigour, therefore, the human subjects must be willing to be involved in such rigour. Every institution has its own rules regarding the plagiarism checks, and it is therefore expected of researchers to be acquainted with the practice.

Other ethical issues to be considered by every researcher in the field of adult and community education are:

$>$ Researchers must offer reciprocity (allowance of access to data, availing time for respondents or adults to fill the questionnaire or in other cases, to be interviewed when they are willing) to the participants,

$\triangleright$ Researchers must ensure that funding and sponsorship are well intact, and also ensure that the conditions given by the funding organisations are well considered before embarking on the research,

$\triangleright$ Researchers must ensure that their works or research projects are original, that it can be validated and replicated in any similar context,

$>$ Researchers must ensure that senior scholars or colleagues are well informed before adding their names, especially for research papers; and also, researchers must ensure these concerned persons participated actively in the course of research,

$>$ Researchers must be open-minded and willing to draw out or inform their participants about the scope, objectives, purpose, and benefits of the study, without exaggeration or underestimation of benefits attached to it. 
From a philosophical approach, it would be expedient to bring to the fore the categorical imperatives of Immanuel Kant. The first law states that human beings should act in such a way that the action can become a universally accepted one. For this, an action must be exhibited in such an ethical way, worthy of emulation, and seen as that of an exemplary model. For the second categorical imperative, the emphasis lies on how one treats others, simply not as a means to an end or as an object, but always at the same end, seeing fellow beings as that of self. Therefore, those involved in research activities in the field must be willing to consider and treat the participants or community members the same way they would want to be treated. The last imperative emphatically stresses the notion of being independently motivated without fear of external threats or influence. The emphasis here is not of the stance that researchers should not follow the ethical considerations established, but rather each researcher in adult and community education must be motivationally independent and determined to set and follow self-rules as and when due, without external influence or external forces. In other words, an efficient researcher in this manner will not wait to be cautioned or sanctioned before they decide what is ethical or unethical. In such a manner, if the law of autonomy and law of humanity are well imbibed by the researchers in the field, there is a tendency that such acts could become a universal law for all and sundry to follow.

\section{Conclusion}

Ethics in adult education research is a major issue to be considered, not only by academics, but by all stakeholders in education and development sectors, both in Nigeria and other nations in Africa. Community-based adult literacy programmes, where majority of adult participants usually sought, are introduced to take care of functional literacy needs of the participants, many of whom are older adults interested in knowledge acquisition for day-to-day relevance. While these learners could be seen as open learners with no strict curriculum or study routine, their privacy and confidentiality must be protected during data collection or information gathering exercises.

Adult education practitioners themselves have a pivotal role to play in specifically defining what constitutes ethics in adult education research. The Federal Ministry of Education in Nigeria, through the National Commission for Mass Literacy, Adult and Nonformal Education must develop a framework that will guide adult education researchers and practitioners in the country on specific ethical procedures to follow while conducting research in adult education, especially the ones involving data collection from the older adult members of the community. One key step to achieving this is the establishment of a unit for Research Ethics and Quality Control by all agencies and institutions promoting adult education research in Nigeria.

In conclusion, adult educators must work with the consciousness that adult learners have experiences they want to share, responsibilities they want to discharge, and integrity they want to protect. They also have emotions that they wish to share, and selfesteem they would not like to be lowered. Therefore, a strong ethical framework is needed for adult education researchers to take caution of while navigating a research terrain involving adult learners. 


\section{Acknowledgements}

No body or funder to acknowledge.

\section{Authors' contributions}

Olaniran, Sunday Olawale conceptualised the topic and reviewed adult and community education and other key variables addressed in the paper. Baruwa, I.B. handled the review of ethics and ethical considerations in Adult and community education. The author(s) read and approved the final manuscript.

\section{Funding}

No funding is received towards this paper.

\section{Availability of data and materials}

We attest that this is a review article and no data set is associated with the article.

\section{Competing interests}

We declare no competing interest.

\section{Author details}

${ }^{1}$ Education Leadership and Management, University of Johannesburg, Johannesburg, South Africa. ${ }^{2}$ Department of Adult Education, University of Ibadan, Ibadan, Nigeria.

Received: 23 June 2020 Accepted: 28 September 2020

Published online: 28 October 2020

\section{References}

Adekola G (2012) Establishing a link between adult education and community development for improved teaching, learning and practice of the concepts. Glob J Educ Res 11(1):65-72

Aderinonye RA (2004) Adult and non-formal education and the global challenges: issues and perspectives. Gabesther Educational Publishers, Ibadan

Akaranga SI, Makau BK (2016) Ethical considerations and their applications to research: a case of the University of Nairobi. J Educ Policy Entrep Res 3(12):1-9

Akintayo MO, Oghenekhowo J (2004) Developing adult education and community development. Research and Study Group, Ibadan

Anyanwu CN (2002) Community education: the African dimension. Department of Adult Education, University of Ibadan, Ibadan

Ayodele JB, Adedokun MO (2012) Towards achieving functional adult literacy in Nigeria. Eur Sci J 8(5):209-218

Babbie E, Mouton J (2001) The ethics and politics of social research. The practice of social research, pp 10-11

Baruwa IB (2020) A revision of Kola Babarinde's stance on value statements in education. Int J Emerg Issues Early Childhood Educ 2(1):11-17. https://doi.org/10.31098/ijeiece.v2i.186

Bekier, M.S. (2010). The Ethical Considerations of Medical Experimentation on Human Subjects. Retrieved at: https://www.qcc. cuny.edu/socialsciences/ppecorino/medical_ethics_text/chapter_7_human_experimentation/Reading-Naziexperimentation.htm. Accessed on: 20 June 2020

Brockett RG (1990) Early ideas on the training of leaders for adult education. The development of adult and worker's education in North America, Breaking New Ground, pp 64-82

Burns N, Grove SK (2005) The practice of nursing research: conduct critique and utilisation, 5th edn. Elsevier/Saunders, St. Louis

DePoy, E., and Gitlin, L. N. (2019). Introduction to research E-book: understanding and applying multiple strategies. Elsevier Health Sciences

DeTienne KB, Ellertson CF, Ingerson M, et al (2019) Moral Development in business ethics: an examination and critique. J Bus Ethics. https://doi.org/10.1007/s10551-019-04351-0

Federal Republic of Nigeria (2013). National Policy on Education: 6th Edition. Retrieved at https://educatetolead.files. wordpress.com/2016/02/national-education-policy-2013.pdf (21/09/2020)

Findsen B (2006) Access and participation issues in New Zealand adult, community, and tertiary education as social justice in: Akpovire, Oduaranm and Harbans S. Bhola, (eds), widening access to education as social justice. Springer, The Netherlands

Frankena KW (2001) Ethics. Prentice Hall, New Delhi, India

Freire P (1973) Education for critical consciousness. Seabury Press, New York

Gordon M (1997) In: Gordon WM (ed) Ethical Issues and Codes of Ethics: Views of Adult Education practitioners in British Columbia. The University of British Columbia, Vancouver, p 1978

Grady C (2018) Ethical principles in clinical research. In: Principles and practice of clinical research. Academic Press, Amsterdam, pp 19-31

Gregson JA, Sturko PA (2007) Teachers as adult learners: re-conceptualising professional development. J Adult Educ 36(1):1-18

Kanukisya B (2018) Ethical challenges in conducting comparative adult education research: personal reflections from multisite research. Department of Comparative and International Adult Education, School of Education, University of Dar es Salaam, Tanzania Available at: https://journals.udsm.ac.tz/index.php/ped/article/view/1477

Knowles MS, Holton EF III, Swanson RA (2005) The adult learner (6 ed). Elsevier, London

Kour J, Verma D (2014) Steganography techniques-a review paper. Int J Emerg Res Manag Technol 3(5):132-135

Mugenda O (2003) Research methods. Qualitative and quantitative approaches. African Center for Technology Studies (ACTS), Nairobi

Olaniran SO (2013) Towards meeting EFA goals by 2015: assessment of literacy-by-radio in Nigeria. Int J Lit 19(3):169-179 
Olaniran SO (2020) Literacy library and the functional literacy skills of the 21st century adult learners. Library Philosophy and

Practice (e-journal), p 3573 Retrieved at: https://digitalcommons.unl.edu/libphilprac

Rodrigues KJ (2012) It does matter how we teach math. J Adult Educ 41(1):29-33

Ryen A (2004) Ethical issues. In: Seale C, Gobo G, Gubrium J, Silverman D (eds) Qualitative research practice. Sage, London, pp $230-247$

Sieber JE (1996) Typically unexamined. Research Ethics: A Psychological Approach, p 73

Susan, I. (1991). Ethical practice in adult education. ERIC Clearinghouse on Adult Career and Vocational Education Columbus OH. Retrieved at: https://eric.ed.gov/?id=ED338897. Accessed 30 May 2020

White MG (2020) Why human subjects research protection is important. Ochsner J 20(1):16-33

Xin, G. (2017). The ethics of reciprocity in translation: the development of a cross-cultural approach/Xin Guangqin. Retrieved from: https://repository.hkbu.edu.hk/etd_oa/367/. Accessed 05 Sept 2020

Zuofa CC (2017) Sustaining adult education and social change in Nigeria. Adv Soc Sci Res J 4(23):146-152

\section{Publisher's Note}

Springer Nature remains neutral with regard to jurisdictional claims in published maps and institutional affiliations.

- fast, convenient online submission

- thorough peer review by experienced researchers in your field

- rapid publication on acceptance

- support for research data, including large and complex data types

- gold Open Access which fosters wider collaboration and increased citations

- maximum visibility for your research: over $100 \mathrm{M}$ website views per year

At $\mathrm{BMC}$, research is always in progress. 